\title{
鼻腔病態生理から見た慢性副鼻腔炎
}

\author{
東北大学医学部耳鼻咽喉科学教室 \\ 池田勝久下村明大島猛史 \\ 平野浩二＼cjkstart鈴木秀明＼cjkstart古川正幸 \\ 須納瀬 弘稲村直 樹高坂知節
}

\section{Pathophysiological Aspects of Chronic Sinusitis}

\author{
Katsuhisa Ikeda, Arira Shimomura, Takeshi Oshima, Koji Hirano, Hideaki Suzuki, \\ Masayuki Furukawa, Hiroshi Sunose, Naoki Inamura, Tomonori Takasaka
}

Department of Otorhinolaryngology, Tohoku University School of Medicine, Sendai

We investigated the pathophysiological aspects of chronic sinusitis in view of 1) the effects of chronic sinusitis on the lower respiratory tract, 2) histopathological findings with special reference to adhesion molecules, 3) the inhibitory effects of medical treatment on nasal secretion, and 4) underlying mechanisms of recovery of mucociliary function following endoscopic sinus surgery, and revealed the following.

1) Chronic sinusitis is a triggering factor for bronchial hyperresponsiveness.

2) Inflammatory cells in the sinus mucosa were infiltrated by ICAM-1.

3) Hyperrhinorrhea is reduced by the inhibitory effects of a variety of drugs on ion transport.

4) Recovery of mucociliary function in the maxillary mucosa was confirmed.

Key words : 慢性副鼻腔炎, 下気道, 接着分子, 鼻汁分泌, 内視鏡下副鼻腔手術

\section{I 緒言}

本論文は慢性副鼻腔炎の全身疾患から見た位置付け とその病態形成を検討し, その保存的及び外科的治療 における背景因子について言及する。

まず最初に慢性副鼻腔炎による下気道への影響, 第 二に病的副鼻腔粘膜の病理的検討，第三に治療におけ る基礎的検討で, 薬物療法と内視鏡下副鼻腔手術の治 癒機序について検討した。

\section{II 下気道への影響}

1) 目的

慢性副鼻腔炎は放置しておいても, 生命予後に直接
的な関与は示さないと認識されるために，特に高齢者 に対して消極的な治療をとる傾向になりがちである。 慢性副鼻腔炎の治療の重要性を確認するために，我々 は生命予後や Quality of Life に直接に関係する下気 道の機能への影響について注目した。副鼻腔気管支症 候群は慢性副鼻腔炎に下気道疾患を合併した症候群で わが国では，粟田口 ${ }^{1)}$ は慢性副鼻腔炎患者の $5.3 \%$, 洲崎 ${ }^{2)}$ は $10.4 \%$ に存在することを報告している。この ように既に完成された下気道病変を有する症例では, 上，下気道両者間の影響を調べることは困難である。 そこで副鼻腔病変と下気道病変の因果関係を証明する 方法として, 治療による副鼻腔病変の除去が与える下 気道病変の変化を検討することが挙げられる。

$-(272) \quad 16-$ 
Slavin $^{3)}$ や Rachelefsky ${ }^{4)}$ は副鼻腔炎を伴う喘息患者 において副鼻腔病変の改善により喘息の改善を報告し ている。近年柳 ${ }^{5)}$ らは副鼻腔気管支症候群患者に内視 鏡下鼻内手術を施行し，下気道機能の有意な改善を報 告している。一方, 市村6) は副鼻腔根本手術後でも下気 道病変の好転は少ないと報告している。このような一 連の研究成果により慢性副鼻腔炎は喘息や気管支炎に 合併し, その下気道病変の形成や増悪の因子となるこ とが示唆されている。以前より下気道病状のない慢性 副鼻腔炎患者において種々の検查による下気道病変の 発見が試みられている788)。しかしながら，下気道病変 の形成以前の慢性副鼻腔炎の下気道に対する影響につ いての直接的な研究は乏しいのが現状である。

そこで, 我々は気道過敏性に注目して検討した。気 道過敏性とは, 気道が非特異的刺激に敏感なことを意 味し, 臨床的にわずかな濃度のアセチルコリンやヒス タミンにより狭窄を生じる性質と定義され，喘息発作 や重症度, 慢性閉塞性肺疾患の肺機能に相関すること が知られている9 。また, 無症候性の気道過敏性陽性例 は高率に喘息に移行し, 下気道病変発症の予後因子と なり得る10)。

2) 対象と方法

明らかな下気道やアレルギー性鼻炎の症状を示さ ず，通常の呼吸機能検查正常の慢性副鼻腔炎患者を対 象に下気道過敏性検査を施行した。スキンテスト, $\mathrm{IgE}$ RIST RAST よりアトピーの有無を調べた。下気道過 敏性検查はアストグラフ法によるメサコリンの連続吸 入中の呼吸抵抗を測定し, 呼吸抵抗の上昇し始めるメ サコリンの閾值の累積を $\mathrm{D}_{\min }$ と定義して, 過敏性の指 標とした。また 7 症例で, 内視鏡下副鼻腔手術後 6 か ら 12 ケ月してから再検し術前と比較した。

3) 結果と考察

慢性副鼻腔炎患者 40 症例のうち $72.5 \%$ が下気道過 敏性を示した。この值はアレルギー性鼻炎の $78.0 \%$ に 相当していた。

年齢による影響では， 60 歳未満 $63.3 \% ， 60$ 歳以上 $75.0 \%$ とや高齢者で陽性率の高い傾向を認めたが, 有意差はなかった。また喫煙とアトピーによる影響に も有意な差は認めなかった。

7 症例において内視鏡下副鼻腔手術により副鼻腔病 変が治癒した後で, 気道過敏性を再検した。メサコリ ンによる感受性を示す $D_{\min }$ は有意に改善しており, 5 症例では過敏性はほほ正常範囲となっていた（図 1 )。

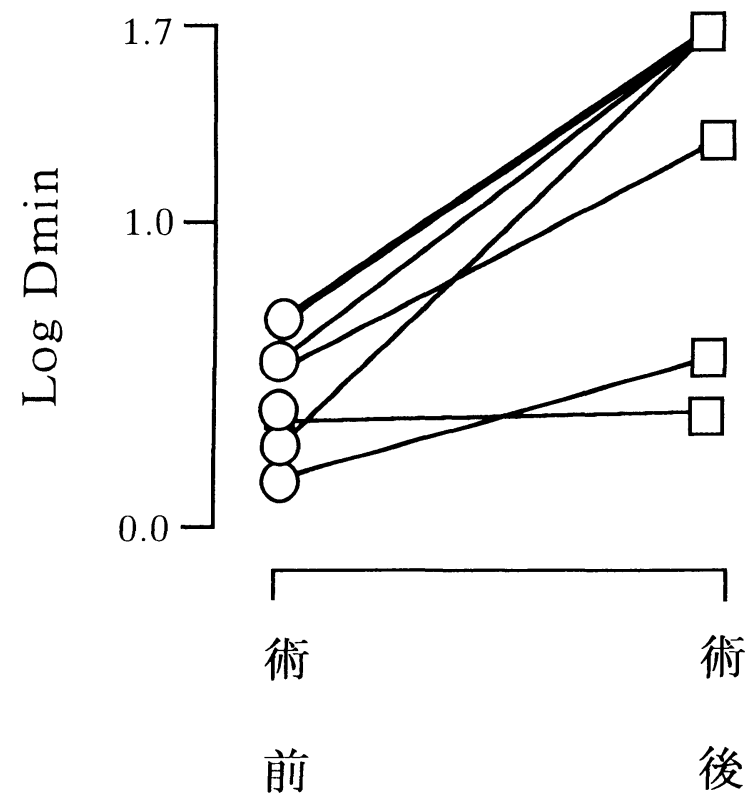

図 1 下気道過敏性（Dmin）の術前後の変化

以上より, 慢性副鼻腔炎患者は $72.5 \%$ と高率に下気道 過敏性を認め, 慢性副鼻腔炎の治療によって過敏性は 改善した。年齢, 喫煙, アトピーは過敏性の成績に影 響を与えなかったことにより, 慢性副鼻腔炎自体が下 気道過敏性を直接引き起こす要因であることが判明し た。また,これは副鼻腔気管支症候群の成因として下 行説を支持する結果である。積極的な鼻副鼻腔への治 療が下気道疾患の合併を予防し, 高齢者の Quality of Life の向上が期待できる。

\section{III 粘膜の病理学的検討}

1) 目的

従来より慢性副鼻腔炎のポリープや病的粘膜の組織 像として浮腫型, 細胞浸潤型, 線維型などの分類がな され ${ }^{11}$, 加齢によって結合組織への增加が生じ, 腺組織 への密度が減少することが知られている ${ }^{12)}$ 。しかしな がら, 近年の免疫組織学の進歩に伴い, 新しい観点か ら病理像を見直す必要性が迫ってきた。種々の研究よ り炎症の成立にはケミカルメディエーターやサイトカ インが血管内皮細胞を活性化させ，接着分子を発現さ せ，顆粒球の内皮細胞との接着と血管外への遊走が生 じて組織障害を生じせしめることが明らかにされつつ ある。組織型に加えて浸潤細胞, 接着分子の面から解 


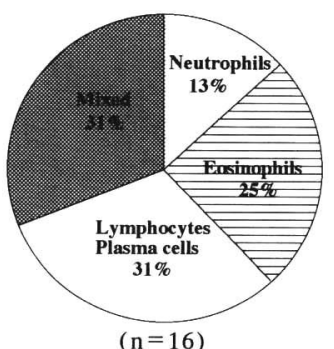

血管・腺增生と上皮肥厚

(一)

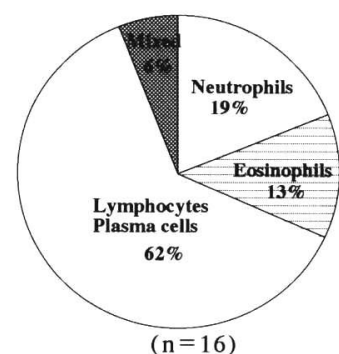

血管・腺増生と上皮肥厚 $(+)$
図 2 慢性副鼻腔炎の炎症性細胞浸潤と組織像

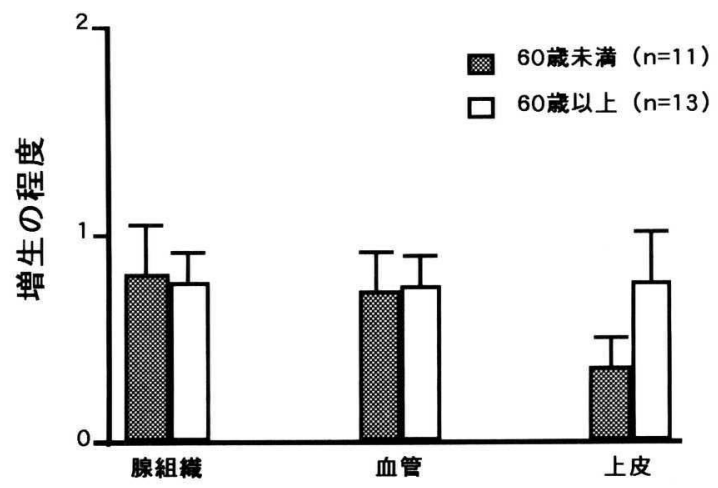

図 3 年齢による増生への影響

析を加えた。

2) 対象と方法

慢性副鼻腔炎患者において手術時に篩骨洞粘膜を採 集し，ヘマトキシン・エオジン染色にて炎症浸潤，血 管と腺増生, 上皮肥厚を観察した。また接着因子とし て ICAM-1 と E-selectionの発現を免疫組織学的に 検討した。

3）結果と考察

血管と腺増生や上皮肥厚を認めた群と認めなかった 群に分けて浸潤細胞の種類について対比した（図 2)。 増生のあまり認められない群では好中球浸潤型, 好酸 球浸潤型, リンパ球浸潤型が同程度にあった。一方, 増生の認められる群では厌倒的にリンパ球や形質細胞 の浸潤するタイプが多く, 何らかの增殖因子の関与が 示唆された。加跉の観点から分析すると腺組織や血管 の増生は 60 歳未満, 以上とも差異は認められなかった (図 3 )。上皮肥厚は有意差はなかったが，高齢者で顕 著な傾向があり，炎症の遷延の結果であることが推察
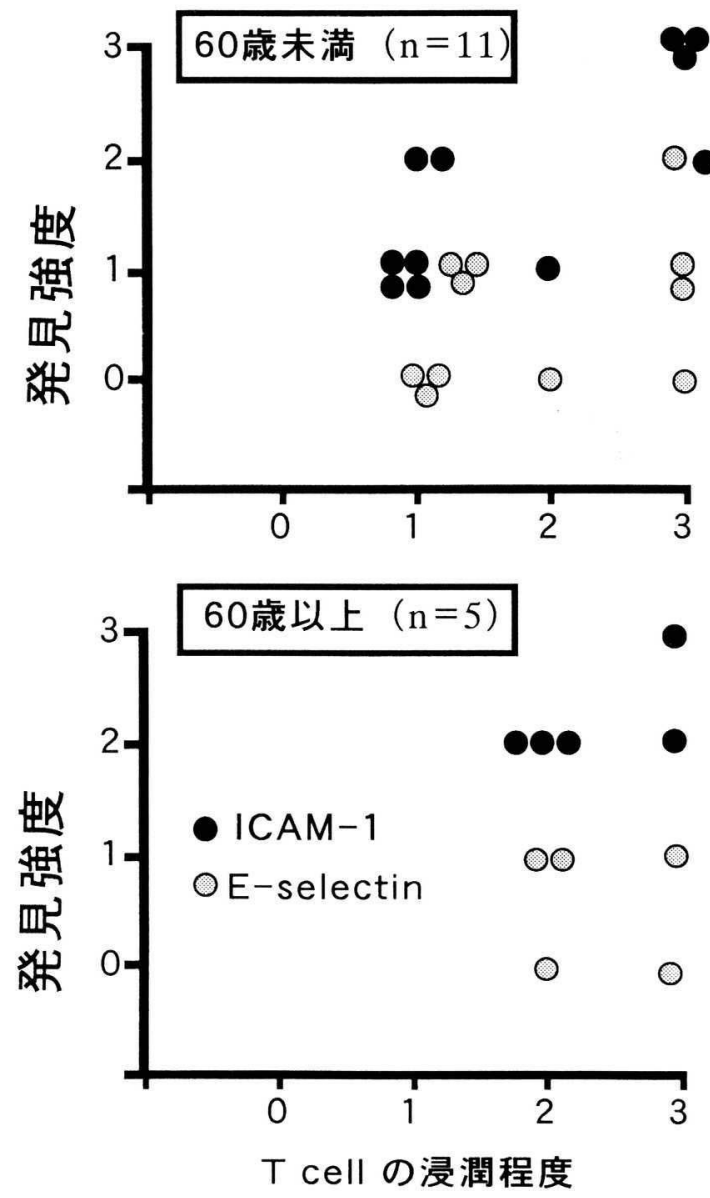

図 4 年齢による接着因子と T cell 浸潤との 関係への影響

された。

好酸球は，異物や毒素を排除したり上皮再生の善玉 の役割に加えて近年は上皮障害や過敏性などの悪玉と しての役割が注目される。最近の 3 年間の慢性副鼻妿 炎症例では好酸球の浸潤は約半数に認められ，アレル ギー性鼻炎とほ湮同程度だった。喘息などでは好酸球 の局所浸潤に V-CAM の関与が証明されているが，慢 性副鼻腔炎ではその発現を認めることができず，他の 因子が関与していることが示唆された。リンパ球と好 中球の局所浸潤に重要とされているICAM-1 と E-selectin の発現と T cell の浸潤程度をそれぞれ 4 段階に評価し,両者の関係を 60 歳以上と末満とで検討 した。年齢にかかわらず ICAM-1 がT cell の浸潤に 


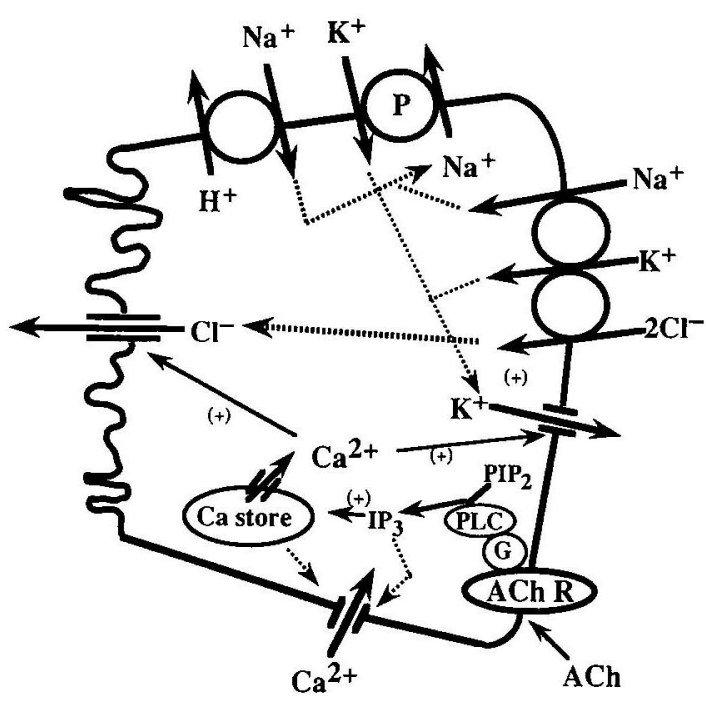

図 5 鼻腺腺房細胞の分泌の細胞モデル

E- selectinよりも相関があることがわかる(図 4)。60 歳以上で強い T cell の浸潤が認められ, 炎症の遷延化 を反映していると考えられる。

以上を要約すると,リンパ球や形質細胞の浸潤型が 主体で血管, 腺增生と上皮肥厚との関連が示唆された。 半数で認められた好酸球の浸潤には V-CAM 以外の 要因が示唆された。高齢者において ICAM-1により T cell が強く漫潤し，炎症の遷延化を反映していると考 えられる。

\section{IV 鼻汁分泌への薬物療法の基礎的検討}

\section{1) 目的}

過剩な鼻汁分泌は慢性副鼻腔炎の主症状である。鼻 汁の由来には血管からの漏出，杯細胞などの粘膜の lining cell からの分泌に加えて, 特に副重腔炎では鼻 腺からの分泌が極めて重要とされている。図 5 はこれ まで我々が明らかにしたモルモットの粘膜下の鼻腺腺 房細胞のアセチルコリンによる分泌の細胞モデルであ

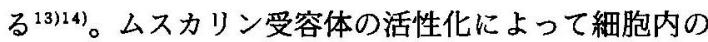
Ca プールからの Ca の動員と細胞外からの流入が生 じ, 細胞内 $\mathrm{Ca}$ 濃度が上昇する。細胞内 $\mathrm{Ca}$ の増加は, 膜の $\mathrm{Cl}$ と $\mathrm{K}$ チャネルを活性化させ, 電解質と水の分 泌が生じる。薬物の作用機序として細胞内 $\mathrm{Ca}$ の増加 と膜のチャネルへの影響を注目することによって, 細 胞および膜レベルでの分泌抑制を説明することが可能

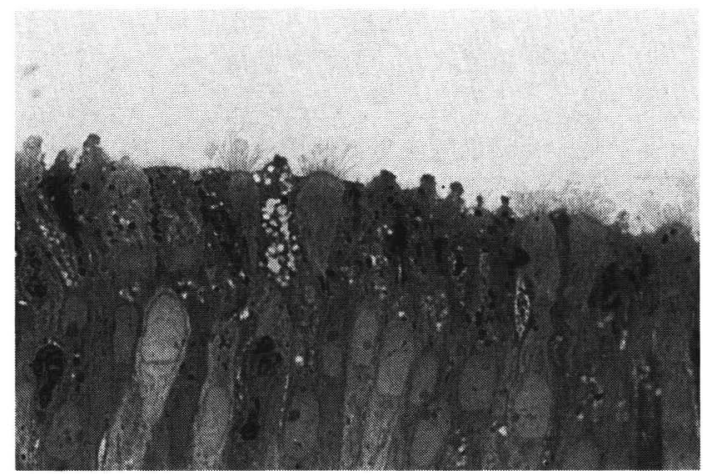

$\mathrm{a}:$ 術前

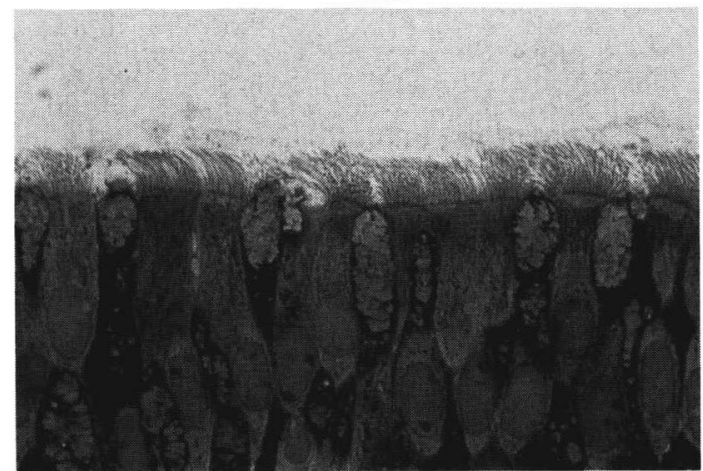

b : 治療後

図 6 慢性副鼻腔炎の上顎洞粘膜の組織像 となる。

2) 対象と方法

モルモットの鼻中隔から上皮層を傷つけずに鼻腺腺 房細胞を切り出し, 0.2 から $0.5 \mathrm{~mm}$ に細切した。コラ ゲネースによる酵素処理を施し，細胞を分離した。単 離した鼻腺腺房細胞に細胞内 $\mathrm{Ca}$ 蛍光指示薬である fura-2 を負荷し，虽光顕微鏡によって蛍光度を観察 し, 画像解析装置によって細胞内 $\mathrm{Ca}^{2+}$ 濃度を解析し た。

鼻腺細胞の膜のイオン電流の測定はパッチクランプ 法を用いた。パイペット電極を鼻腺腺房細胞の膜に接 触させ, whole-cell mode を作り, 膜電位は $-40 \mathrm{mV} に$ 固定して,それぞれ $\mathrm{Cl}$ と $\mathrm{K}$ の逆転電位である $0 \mathrm{mV}$ と $90 \mathrm{mV}$ の二段パルスによる電位刺激を行った。

種々の楽物の細胞内 $\mathrm{Ca}^{2+}$ 濃度とイオン電流への影 響を検討した。

3）結果と考察

抗アレルギー剤としてオキサミド，KW-4679，小青 
竜湯，慢性副鼻腔炎に対して近年頻用されてきたマク ロライド系抗生物質, キサンチン誘導体についての結 果を表 1 にまとめた。

以上より, 鼻副鼻腔疾患に使用される薬剤の鼻汁分 泌への抑制作用は, オキサトミドはチャネルの阻害作 用, KW-4679 と小青竜湯は抗コリン作用, マクロライ

表 各種薬物の鼻腺腺房細胞分泌への影響

\begin{tabular}{c|ccc}
\hline & $\begin{array}{c}\text { 細胞内 } \\
\mathrm{Ca}^{2+} \text { 応答 }\end{array}$ & $\mathrm{K}^{+}$電流 & $\mathrm{Cl}^{-}$電流 \\
\hline オキサトミド & 不変 & 抑制 & 抑制 \\
\hline $\mathrm{KW}-4679$ & 抑制 & 抑制 & 抑制 \\
\hline 小青竜湯 & 抑制 & 抑制 & 抑制 \\
\hline エリスロマイシン & 不変 & 不変 & 抑制 \\
\hline キサンチン誘導体 & 抑制 & \multicolumn{2}{|c}{ 施行せず } \\
\hline
\end{tabular}

\section{〈術直後例〉}

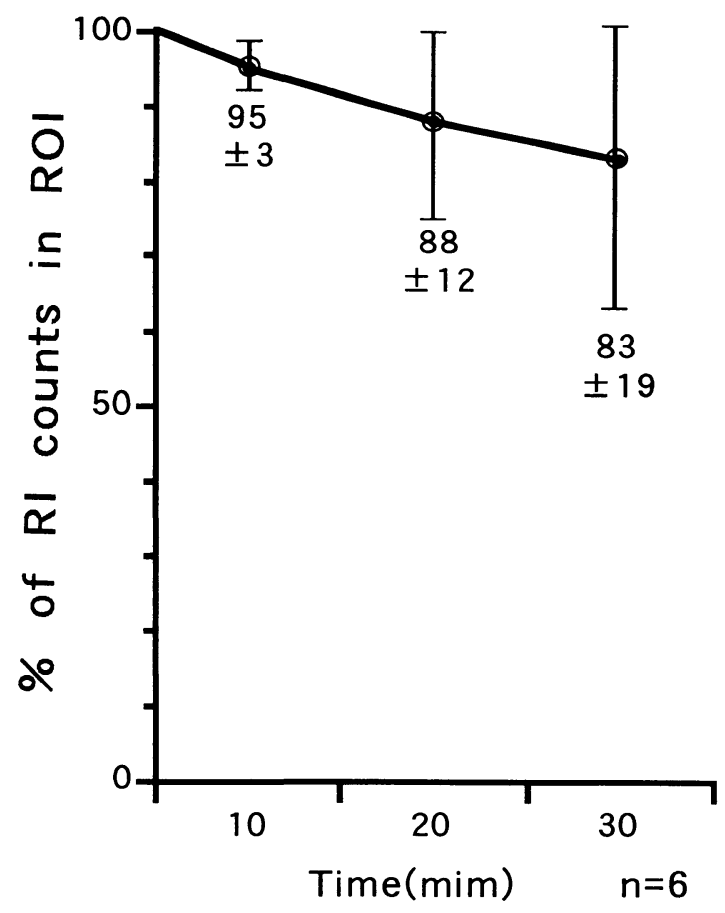

$\mathrm{a}:$ 術直後
ド抗生㓮は直接的な $\mathrm{Cl}$ チャネルの阻害作用, キサンチ ン誘導体は $\mathrm{Ca}$ 動員と流入の阻害作用によって説明さ れた。

\section{$\mathrm{V}$ 内視鏡下副鼻腔炎手術の粘液線毛輸送への 影響}

1) 目的

最後に内視鏡下副鼻腔手術における上顎洞の粘液線 毛輸送の改善について検討した。近年広く普及してき た内視鏡下副鼻腔手術において術後の特に上顎洞粘膜 の治癒機序として, 排泄と換気路の獲得と粘液線毛運 動の改善が必要である。排泄路の疎通性は内視鏡に よって直接に観察が可能だが, 上顎洞の粘液線毛輸送 機能の客観的な評価は困難とされてきた。今回, 上頜 洞上皮の線毛の形態学的観察, 上顎洞の粘液線毛輸送 の測定, 摘出された上顎洞粘膜の in vitro下の線毛運 動の観察を, 手術直後と治癒後に施行し, 比較検討し

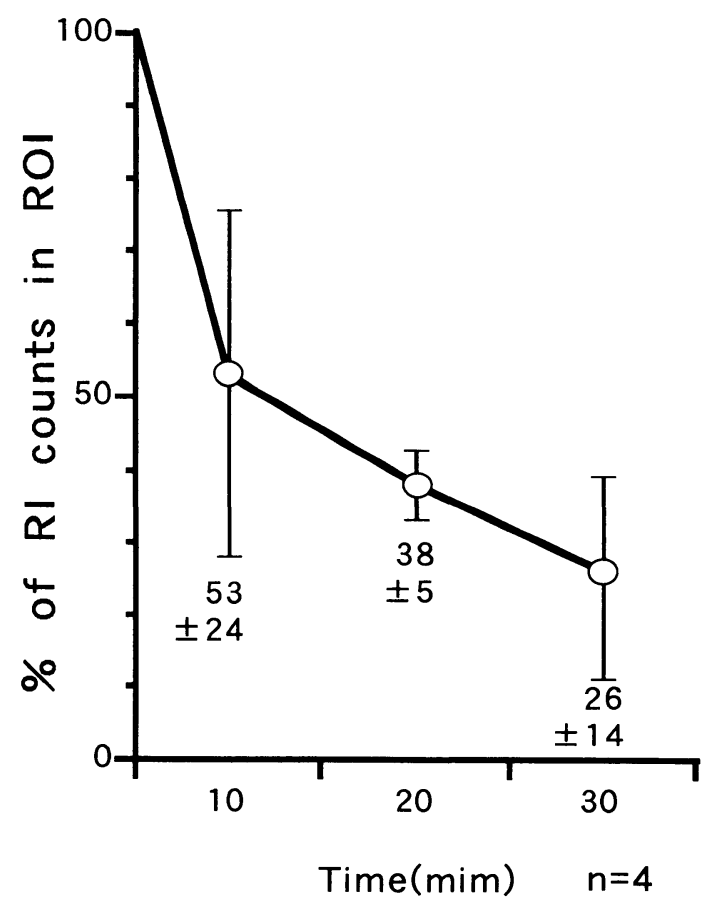

$\mathrm{b}$ : 治療後

図 7 慢性副鼻腔炎の上顎洞の粘膜緎毛運動 
た。

2) 対象と方法

慢性副鼻腔炎患者の上顎洞粘膜を術中と治療後に採 集し, 線毛の光学顕微鏡レベルの組織学的観察と高速 ビデオカメラによる繊毛運動の観察を行った。また術 直後と治療後に ${ }^{99 m} \mathrm{Tc}$ ラベルのアルブミンを開大さ

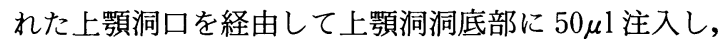
その移動を 30 分間シンチレーションカメラにて観察 した。

\section{3）結果と考察}

術中に採集した粘膜では線毛を認めない上皮細胞が 多く, 線毛細胞の線毛数も減少していた。一方, 同症 例の治瘉後では, 粘膜はほほ一面に渡り線毛数の豊富 な線毛細胞によって被われているのが判明した。

術中または治瘾後に上顎洞粘膜を採集し，微分干涉 の倒立顕微鏡下で観察し高速ビデオによって 1 秒間に 250 コマの率で線毛運動を撮影した。病的粘膜と治痹 粘膜の繊毛運動を比較すると, 前者でその協調運動の 阻害を認めた。

上顎洞に置いた ${ }^{99 \mathrm{~m}} \mathrm{Tc}$ の時間経過に伴う残存率を 求めることにより, 上鿓洞の粘液瀻毛運動の評価とし た(図 7 )。 ${ }^{99 \mathrm{~m}} \mathrm{Tc}$ の残存率は手術直後例では 30 分後で 平均 $83 \%$, 粘膜病変改善例では平均 $26 \%$ と有意な差が あり, 上顎洞の粘液線毛輸送機能の六進が客観的に認 められた。

内視鏡下副鼻腔手術により上顎洞の粘液線毛運動機 能は線毛の形態, in-vitro下での線毛運動, in-vivo で の粘液線毛運動の観点から改善が証明された。しかし ながら, 上顎洞の粘液の性状, 粘液と線毛の相互作用 については今回の研究では言及することはできず，今 後の課題となる。

\section{VI 結 語}

下気道疾患の発展を予防し快適な Quality of Life を過ごす意味から，高歯者の副鼻腔炎患者に対して 個々の症例の病態に沿った薬物療法や内視鏡下副鼻腔 手術と術後治療によって完治させることが重要である と考えられる。

\section{文献}

1）粟田口省吾: 副鼻腔気管支炎. 気食会報 27 : 264-269, 1976.

2) Suzaki H, Kudoh S, Sugiyama $Y$ et al: Sino- bronchial syndrome in Japanese people. Am J Rhinol 4 : 133-139, 1990.

3) Slavin RG: Relationship of nasal disease to sinusitis to bronchial asthma. Ann Allergy 49: 76-80, 1982.

4) Rachelefski GS, Katz RM, Siegel SC: Chronic sinus disease with associated reactive airway disease in children. Pediatrics $73: 526-9,1984$.

5）柳清 - 他：慢性副鼻腔炎と下気道疾患一保存 的鼻内手術の効果一. 第 95 回日本耳鼻咽喉科学 会総会 1994 .

6）市村恵一, 洲崎春海, 土田みね子・他: 副鼻腔気 管支症候群における副鼻腔手術の問題点. 耳喉 50:469-479, 1978.

7）高北晋一, 北村溥之, 庄司和彦・他：慢性副鼻腔 炎における肺機能一副鼻腔気管支症候群との関連 一. 耳鼻臨床 $85: 4 ; 589-596,1992$.

8）大塚健蔵，金高真人，山口道也・他：非喫煙慢性 副鼻腔炎患者の末梢気道病変の検討. 日気食会報 40:55-60, 1989.

9) Hopp RJ, Townley RG, Biven RE, et al: The presence of airway reactivity before the development of asthma. Am Rev Respir Dis 141: 2-8, 1990.

10) Yan K, Salome CM, Woolcock AJ : Prevalence and nature of bronchial hyperresponsiveness in subjects with chronic obstructive pulmonary disease. Am Rev Respir Dis 132: 25-29, 1985.

11）石川保之：鼻茸摘出後の再生因子の検討耳鼻臨床 83: 1385-1389, 1990.

12）八尾和雄: 老人と副鼻腔炎: 野村恭也, 本庄 嚴 編: 耳鼻咽喉科・頭頸部外科 MOOK. 金原出版, 東京 $258-264,1989$.

13) Sunose $\mathrm{H}, \mathrm{Zhang} W$, Ishigaki $M$, et al : Isolation of acini from nasal glands of the guinea-pig. Acta Physiol Scand 151 : 377-384, 1994.

14) $\mathrm{Wu} \mathrm{D}$, Sunose $\mathrm{H}$, Ikeda $\mathrm{K}$, et al : Ionic currents induced by acethylcholine in isolated acinar cells of the guinea pig nasal gland. Biochem Biophys Res Comm 202 : 307-313, 1994.

（1994 年 11 月 7 日受稿， 1994 年 11 月 17 日受理） 